\title{
INSTYTUCJONALNE UWARUNKOWANIA WYDŁUŻANIA OKRESU AKTYWNOŚCI ZAWODOWEJ²
}

\begin{abstract}
Wydłużanie okresu aktywności zawodowej to istotny kierunek polityki społecznej ostatnich lat. Determinuje to potrzebę prowadzenie badań nad uwarunkowaniami decyzji emerytalnych. Wyjaśnia je koncepcja czynników push i pull. Hofäcker uzupełnia tę klasyfikację, wymieniając wśród determinant instytucjonalnych również czynniki stay, obejmujące wsparcie zatrudnialności starszych uczestników rynku pracy poprzez różne działania aktywnej polityki rynku pracy oraz lifelong learning.

Celem pracy jest ocena znaczenia czynników instytucjonalnych dla wydłużania okresu aktywności zawodowej w krajach Unii Europejskiej. Analiza empiryczna przeprowadzona została w oparciu o dane LFS, z wykorzystaniem podstawowych metod oceny współzależności oraz analizy skupień. Badanie zrealizowano dwutorowo. Po pierwsze, posługując się metodyką zaproponowaną przez Hofäckera, zaktualizowano wyniki badań zrealizowanych przez niego dla 2010 r., uzupełniając równocześnie analizę o pominięte kraje UE. Wyznaczono na tym etapie syntetyczny wskaźnik oceny instytucjonalnych uwarunkowań wydłużania aktywności zawodowej. W drugim kroku przy pomocy analizy skupień dokonano grupowania krajów UE z punktu widzenia badanego zjawiska (wykorzystując analogiczne jak $\mathrm{w}$ etapie pierwszym charakterystyki). W ostatnim etapie dokonano oceny korelacji między aktywnością zawodową osób starszych a analizowanymi syntetycznie uwarunkowaniami instytucjonalnymi. Wyniki badań wskazują, że w Unii Europejskiej wśród instytucjonalnych uwarunkowań wydłużania okresu aktywności zawodowej oprócz czynników typu pull i push istotne znaczenie odgrywają także determinanty typu stay. Ogólnie rzecz biorąc, omawiane uwarunkowania instytucjonalne w większym stopniu oddziałują na poziom wskaźników zatrudnienia w Unii Europejskiej w przypadku mężczyzn niż kobiet. Słabe znaczenie aktywnej polityki rynku pracy (ALMP) koresponduje z tym, że w odniesieniu do osób w wieku 50 i więcej lat bardziej skuteczne są działania służące utrzymaniu ich w zatrudnieniu niż ponownemu zatrudnieniu po utracie pracy.
\end{abstract}

Słowa kluczowe: starzenie się populacji, polityka rynku pracy, emerytura, UE.

\footnotetext{
${ }^{1}$ Dr hab. Justyna Wiktorowicz, Katedra Statystyki Ekonomicznej i Społecznej, Uniwersytet Łódzki, Łódź, ul. Rewolucji 1905 r. 41; e-mail: justyna.wiktorowicz@uni.lodz.pl Justyna Wiktorowicz, DSc, PhD, Department of Economic and Social Statistics, University of Lodz, Lodz, ul. Rewolucji 1905 r. 41; e-mail: justyna.wiktorowicz@uni.lodz.pl

2 Treści wyrażone w artykule są opiniami autorki i nie przedstawiają stanowiska organów Narodowego Banku Polskiego.

Projekt pt. Forum Dyskusyjne - Pomiar i ocena zjawisk ekonomicznych i społecznych (MASEP2017) realizowany jest z Narodowym Bankiem Polskim w ramach edukacji ekonomicznej.
} 


\section{WPROWADZENIE}

Starzenie się społeczeństw ma poważne konsekwencje dla gospodarek. Z perspektywy makroekonomicznej, zmienia na niekorzyść strukturę populacji, w wyniku czego rośnie obciążenie ekonomiczne, tj. na jedną osobę w wieku produkcyjnym przypada więcej osób w wieku poprodukcyjnym. Rosną tym samym transfery pieniężne, zwłaszcza związane ze świadczeniami emerytalnymi, ale także z usługami realizowanymi w ramach systemu opieki zdrowotnej i pomocy społecznej ${ }^{3}$. Jako jedno z najbardziej efektywnych rozwiązań tego problemu stawia się wydłużenie okresu aktywności zawodowej. Jak wykazali Barrell, Hurst i Kirby ${ }^{4}$, wypłaty transferowe dla emerytów i rencistów ulegają dzięki temu zmniejszeniu, bez konieczności obniżania wysokości świadczeń. Jest to rozwiązanie łatwiejsze dla rządów niż np. podniesienie podatków, zwiększając jednocześnie przychody podatkowe dzięki wzrostowi dochodów i konsumpcji. W tym kontekście istotne jest prowadzenie badań nad uwarunkowaniami decyzji emerytalnych. Wyjaśnia je koncepcja czynników push i pull, tj. wypychających z rynku pracy i wciągających w bierność zawodową ${ }^{5}$. De Preter, Van Looy, Mortelmans w obu grupach czynników wymieniają podgrupę czynników instytucjonalnych i indywidualnych ${ }^{6}$. Hofäcker uzupełnia tę klasyfikację, wymieniając: (1) determinanty instytucjonalne: pull factors - tkwiące w systemie emerytalnym, push factors uwarunkowania po stronie rynku pracy oraz stay factors - polityka aktywnego starzenia się (ALMP i lifelong learning - LLL), (2) determinanty na poziomie organizacji oraz (3) determinanty na poziomie indywidualnym? ${ }^{7}$.

Jako cel niniejszej pracy przyjęto ocenę znaczenia czynników instytucjonalnych typu pull, push i stay dla wydłużania okresu aktywności zawodowej w krajach Unii Europejskiej.

\section{INSTYTUCJONALNE UWARUNKOWANIA DECYZJI EMERYTALNYCH - WNIOSKI Z PRZEGLĄDU BADAŃ}

Czynniki typu pull, wciągające $\mathrm{w}$ emeryturę, tkwią w systemie emerytalnym. Do aktywności zawodowej w starszym wieku zniechęca tradycyjny mechanizm transferów socjalnych, w którym wysokość świadczeń emerytalnych nie jest uzależniona od stażu zawodowego. Jeśli stopa zastąpienia jest wysoka większość osób wybierze emeryturę ${ }^{8}$. Czynniki instytucjonalne typu pull to przede wszystkim dłuższy okres pobierania zasiłku dla

\footnotetext{
${ }^{3}$ M. Polakowski, Spoteczne i ekonomiczne konsekwencje starzenia się spoteczeństw a główne kierunki reform systemów emerytalnych w Europie, „Studia BAS”, 2/30 (2012), s. 169-200.

${ }^{4}$ R. Barrell, I. Hurst, S. Kirby, Macroeconomic implications of pension reform or how to pay for the crisis [w:] Pension Reform, Fiscal Policy and Economic Performance, Workshops and Conferences, Banca d'Italia, Roma 2009, s. 503-514.

${ }^{5} \mathrm{Ch}$. Phillipson, A. Smith, Extending working life: A review of the research literature, Department for Work and Pensions, Research Report No 299, 2005; A. Walker, Early Retirement: Release or Refuge from the Labour Market?, "The Quarterly Journal of Social Affairs", 1/3 (1985), s. 211-229.

${ }^{6}$ H. de Preter, D. van Looy, D. Mortelmans, Individual and institutional push and pull factors as predictors of retirement timing in Europe: A multilevel analysis, "Journal of Aging Studies", 27/2013, s. 299-307.

${ }^{7}$ D. Hofäcker, In line or at odds with active ageing policies? Exploring patterns of retirement preferences in Europe, "Ageing and Society”, 35/7 (2015), s. 1529-1556.

${ }^{8}$ Ł. Jurek, Ekonomia starzejącego się spoteczeństwa, Warszawa 2012, s. 95-97.
} 
bezrobotnych w przypadku starszych osób, łatwiejsze odejście z rynku pracy osoby starszej W związku z możliwością skorzystania z wcześniejszego przejścia na emeryturę, system orzekania niepełnosprawności, możliwość kontynuowania pracy pomimo wcześniejszego przejścia na emeryturę ${ }^{9}$. Istotne znaczenie odgrywa również niestabilność prawa w tym obszarze - zmiany dotyczące przechodzenia na emeryturę powodują, że ludzie chętniej skłaniają się ku decyzji opuszczenia rynku pracy w obawie przed zmianą sytuacji na mniej korzystną dla siebie. Jak piszą Domańska i Zajkowski ${ }^{10}$, w Polsce istotne znaczenie dla relatywnie niskiej aktywności zawodowej osób w wieku 50+ ma przede wszystkim konstrukcja systemu ubezpieczeń i zabezpieczeń społecznych, która stanowi dużą zachętę finansową do przedwczesnego wycofania się z rynku pracy. Realizowane po 2010 r. badania wskazują jednak, że dzięki ograniczeniu możliwości wcześniejszego przechodzenia na emeryturę, stopniowemu wyrównywaniu wieku emerytalnego kobiet i mężczyzn oraz jego podniesieniu do 67 lat w 2013 r. znaczenie czynników typu pull uległo osłabieniu, co przełożyło się na wyraźne podwyższenie współczynnika aktywności zawodowej i wskaźnika zatrudnienia osób w wieku 50+, w tym $55+{ }^{11}$.

Czynniki instytucjonalne typu push obejmują rozwiązania prawne ochraniające w szczególny sposób osoby starsze, oznaczające konieczność wypłaty odszkodowań z tytułu zwolnienia osoby starszej, uzależnienie wynagrodzenia od stażu pracy, wzrost wymagań dotyczących kwalifikacji, spowodowanych przede wszystkim rozwojem nowoczesnych technologii i globalizacją, mniejszą elastyczność pracowników w związku ze starzeniem się siły roboczej ${ }^{12}$. Do grupy tej zalicza się również dyskryminację ze względu na wiek $^{13}$ oraz możliwości zatrudnienia starszych pracowników na lokalnym rynku pracy w sytuacji ogólnych trudności na rynku pracy starsi pracownicy wybiorą raczej emeryturę ${ }^{14}$.

Determinanty typu stay z kolei obejmują dwa istotne elementy polityki aktywnego starzenia się - wsparcie zatrudnialności starszych uczestników rynku pracy poprzez różne działania aktywnej polityki rynku pracy (ALMP) oraz kształcenie ustawiczne (LLL). Odnosząc się do polityki rynku pracy zaznaczyć należy, że niskie wydatki na ALMP

9 L. Funk, Employment Opportunities for Older Workers: A Comparison of Selected OECD Countries, DICE Research Report 2004, s. 24; A. Chłoń-Domińczak, Ekonomiczne skutki i uwarunkowania niskiej aktywności zawodowej osób 50+ w Polsce [w:] Aktywizacja zawodowa osób 50+ i zarzadzanie wiekiem, Informacje użyteczne dla instytucji rynku pracy, Akademia Rozwoju Filantropii w Polsce, Warszawa 2010, s. 16-21.

10 A. Domańska, R. Zajkowski, Raport z badań kluczowych przeprowadzonych na potrzeby realizacji projektu «PI - Wirtualny Asystent Kariery 50+» (WAK50), Lublin 2013, s. 19.

11 M. Bukowski (red.), Zatrudnienie w Polsce 2008. Praca w cyklu życia, Warszawa 2010, s. 29-30; P. Strzelecki, K. Saczuk, I. Grabowska, I.E. Kotowska, Rynek pracy [w:] J. Czapiński, T. Panek (red.), Diagnoza Społeczna 2013. Warunki i Jakość Życia Polaków - Raport, MPiPS, CRZL, Warszawa 2014, s. 129.

${ }^{12}$ L. Funk, Employment Opportunities for Older..., s. 24.

${ }^{13}$ L. Unwin, G. Davey, A. Fuller, P. Leonard, Supporting an Ageing Workforce: Implications for Working Life, Training and Skills Policy in England - a Literature Review, "LLAKES Research Paper" 51, Centre for Learning and Life Chances in Knowledge Economies and Societies, 2015.

${ }^{14}$ W. van Oorschot, P.H. Jensen, Early retirement differences between Denmark and The Netherlands. A cross-national comparison of push and pull factors in two small European welfare states, "Journal of Aging Studies", 23/4 (2009), s. 267-278. 
(zwłaszcza w perspektywie flexicurity) wypychają osoby starsze z rynku pracy ${ }^{15}$, zaś wysokie wydatki na pasywną politykę rynku pracy (PLMP), w tym zwłaszcza zasiłki przedemerytalne, czynią dezaktywizację bardziej atrakcyjną.

Odnosząc się szerzej do uwarunkowań leżących po stronie polityki rynku pracy zauważyć należy, że osoby bezrobotne większe korzyści postrzegają w dostępności do takich zasobów, jak świadczenia emerytalne z ubezpieczeń społecznych - zwłaszcza w sytuacji braku wsparcia finansowego, które umożliwi osobom poszukującym pracy „wytrwanie w poszukiwaniach" (zamiast wybrania łatwiej dostępnej i pewniejszej emerytury). Prawdopodobieństwo przejścia na emeryturę rośnie w przypadku wystąpienia przerwy w zatrudnieniu. Tolerancja bezrobotnych na długie poszukiwania pracy jest niewielka, niezależnie od perspektyw na rynku pracy, co powoduje, że ci, którzy mogą skorzystać z emerytury, robią to jak najszybciej jest to możliwe ${ }^{16}$. Tolerancja, o której mowa, powiązana jest z zamożnością starszych bezrobotnych - ci bardziej zamożni mogą sobie pozwolić na dłuższe poszukiwania pracy, biedniejsi - częściej i szybciej wybierają emeryturę. Wysoka stopa bezrobocia generalnie rzecz biorąc przyczynia się do szybszego wychodzenia z rynku pracy ${ }^{17}$. Niemniej jednak badania Rutledge'a, prowadzone dla USA, nie potwierdzają tego - przejście na emeryturę jest mniej prawdopodobne, jeśli stopa bezrobocia jest wysoka, choć korelacja jest relatywnie słaba ${ }^{18}$. Jak podkreśla Rutledge, relacje te należy odnosić jedynie do bezrobotnych w późnym okresie ich karier zawodowych. Starsi bezrobotni mają bowiem słabą tolerancję na długie poszukiwanie pracy ${ }^{19}$.

Jak ustalił Hofäcker, wcześniejsze doświadczenia związane z byciem bezrobotnym wykazują silną interakcję z reżimem instytucjonalnym ${ }^{20}$. W krajach, w których wsparcie bezrobotnych jest wysokie, doświadczenie bezrobocia przez przynajmniej 12 miesięcy w rzeczywistości wydaje się zachęcać mężczyzn do opóźnienia momentu przejścia na emeryturę. Z kolei w krajach, w których takie wsparcie jest niskie, kobiety obniżają oczekiwany wiek emerytalny, jeśli mają za sobą doświadczenie bezrobocia. Te przeciwstawne efekty mogą być odzwierciedleniem szans na rynku pracy i zróżnicowanych ram instytucjonalnych. W krajach, w których instrumenty ALMP wspierają kontynuowanie zatrudnienia do momentu osiągnięcia powszechnego wieku emerytalnego (a nawet po jego przekroczeniu), sam brak wczesnych możliwości emerytalnych promuje utrzymanie zatrudnienia. Natomiast w krajach o niskim wsparciu zatrudnienia i wysokim bezrobociu, o niskich szansach na znalezienie pracy w sytuacji jej utraty, pracownicy, którzy doświadczyli bezrobocia chętnie skorzystają z możliwości przejścia na emeryturę. Podkreślić przy tym należy, że biorąc

${ }^{15}$ H. de Preter, D. van Looy, D. Mortelmans, Individual and institutional push...

${ }^{16}$ M.S. Rutledge, Point of no return: how do financial resources and the timing of retirement after a Job separation, "Center for Retirement Research Working Paper" 2013-21, Boston College, Boston 2013.

17 A.H. Munnell, M. Soto, R.K. Triest, N.A. Zhiven, How Much o State Economic and Other Characteristics Affect Labor Force Participation of Older Workers?, "Center for Retirement Research Working Paper" 2008-12, Boston College, Boston 2008.

${ }_{18}$ M.S. Rutledge, Point of no return: how do financial...

${ }^{19} \mathrm{~T}$. von Wachter, The effect of economic conditions on the employment of workers nearing retirement age, "Center for Retirement Research Working Paper" 2007-25, Boston College, Boston 2007.

${ }^{20} \mathrm{D}$. Hofäcker, In line or at odds with public policies? Individual retirement preferences in a changing pension landscape, Paper for the ESPAnet Anniversary Conference 2012 Edinburgh, 6-8.09.2012. 
pod uwagę niską stopę zastąpienia w omawianych krajach, ma to negatywne konsekwencje dla sytuacji materialnej tych osób w starszym wieku. Wyniki uzyskane przez Rutledge'a wskazują na słabą zależność między sytuacją na rynku pracy a decyzjami emerytalnymi ${ }^{21}$, potwierdzając jednocześnie znaczenie czynników psychologicznych - ,jednostkowa niecierpliwość" w poszukiwaniu pracy ma niewiele wspólnego z trudnościami w poszukiwaniu pracy ${ }^{22}$. Generalnie rzecz biorąc, recesja nie tylko nie spowolniła tendencji przesuwania w górę granicy efektywnego wieku emerytalnego, ale wręcz ją przyspieszyła. Po 2007 r. odmienne tendencje zaobserwowano w nielicznych krajach UE: dla mężczyzn w wieku 60-64 lata dotyczy to Hiszpanii, Irlandii, Portugalii i Grecji, dla kobiet - Portugalii, dla mężczyzn i kobiet w wieku 65-69 lat oraz w wieku 70-74 lata - również Portugalii ${ }^{23}$.

Co istotne, opóźnienie momentu przejścia na emeryturę nie prowadzi do wzrostu bezrobocia wśród młodych ${ }^{24}$. Dotyczy to zarówno kobiet, jak i mężczyzn, niezależnie od ich poziomu wykształcenia. Prawidłowość ta nie uległa zmianie również w czasie kryzysu. Wynika to z faktu, że podaż pracy młodych i starszych nie jest substytucyjna. Ostatnie pół wieku charakteryzuje się bowiem stałym wzrostem poziomu umiejętności pracowników, ale też stawianych wobec nich wymagań kompetencyjnych, mocno powiązanych z zachodzącymi zmianami technologicznymi. Jak wykazali Kalwij, Kapteyn i de Vos dla krajów OECD wnioski te są analogiczne przy różnych systemach polityki społecznej - zarówno w modelu nordyckim, anglosaskim, jak i śródziemnomorskim wskaźnik zatrudnienia młodych nie ma związku z aktywnością zawodową starszych (rozumianych w tym badaniu jako osoby w wieku 55-64 lata) ${ }^{25}$.

\section{INSTYTUCJONALNY KONTEKST WYDEUŻANIA OKRESU AKTYWNOŚCI ZAWODOWEJ - WYNIKI BADAŃ WŁASNYCH}

\section{1. Źródła danych i metody}

W niniejszej pracy podjęto próbę syntetycznej oceny instytucjonalnego kontekstu aktywności zawodowej w krajach Unii Europejskiej. Analiza empiryczna przeprowadzona została w oparciu o dane Labour Force Surveys (LFS), zaczerpnięte z banku danych Eurostatu.

${ }^{21}$ M.S. Rutledge, N. Orlova, A. Webb, How will Older workers who lose their jobs during the Great Recession fare in the long-run?, "Center for Retirement Research Working Paper" 2013-9, Boston College, Boston 2013.

22 J. Ondrich, A. Falevich, The Great Recession and the retirement decisions of older workers, "Center for Retirement Research Working Paper" 2013-24, Boston College, Boston 2013.

${ }^{23}$ G. Burtless, B.P. Bosworth, Impact of the Great Recession on retirement trends in industrialized countries, "Center for Retirement Research Working Paper" 2013-23, Boston College, Boston 2013.

${ }^{24}$ A. Kalwij, A. Kapteyn, K. de Vos, Retirement of older workers and employment of the young, De Economist, 158/4 (2010), s. 341-359; A.H. Munnell A.Y. Wu, Will delayed retirement by the baby boomers lead to higher unemployment among younger workers?, "Center for Retirement Research Working Paper" 2012-22, Boston College, Boston 2012.

25 Ibidem. 
Badanie zrealizowano dwutorowo. Po pierwsze, posługując się metodyką zaproponowaną przez Hofäckera ${ }^{26}$, zaktualizowano wyniki badań zrealizowanych przez niego dla 2010 r., uzupełniając równocześnie analizę o pominięte przez Hofäckera kraje UE (np. Luksemburg czy Cypr). Wyznaczono na tym etapie syntetyczny wskaźnik oceny instytucjonalnych uwarunkowań wydłużania aktywności zawodowej (institutional factors of extending working life indicator - IFEWL), liczony jako średnia ocena trzech wymiarów efektów polityki państwa - pull, push i stay. Pomiar czynników typu pull wykonano przy pomocy następujących zmiennych cząstkowych: obowiązujący w 2015 r. wiek emerytalny kobiet i mężczyzn i jego planowane zmiany (według stanu na koniec 2015 r.). Czynniki typu push mierzone były poprzez sytuację osób starszych na rynku pracy, której wskaźnikiem była stopa bezrobocia osób w wieku 50-64 lata (według stanu na koniec 2014 r.). Z kolei czynniki typu stay mierzone były poprzez dwa wskaźniki - wskaźnik lifelong learning - LLL (osoby dorosłe uczestniczące w kształceniu i szkoleniu w ostatnich 12 miesięcy, według stanu z 2014 r.) oraz udział wydatków na aktywną politykę rynku pracy w PKB kraju (ALMP, najnowsze dostępne dane dotyczyły 2013 r.). Wartości poszczególnych zmiennych zestawiono w tabeli 1 . Każdej ze zmiennych nadano ocenę punktową (z przedziału od 1 do 4), przy czym im wyższa ocena, tym bardziej kontekst instytucjonalny sprzyja wydłużaniu aktywności zawodowej. W przypadku czynników stay na potrzeby wskaźnika IFEWL wyznaczono średnią z ocen dwóch uwzględnionych zmiennych cząstkowych (LLL i ALMP). Dla zmiennych ilościowych punktację nadawano korzystając z metody odchyleń. Wskaźnik IFEWL obliczono jako średnią arytmetyczną nieważoną z oceny poszczególnych aspektów polityki wspierania wydłużania aktywności zawodowej. Może on zatem przyjmować wartości od 1 do 4, przy czym im wyższa jego wartość, tym bardziej uwarunkowania instytucjonalne sprzyjają wydłużaniu okresu aktywności zawodowej.

W drugim kroku zastosowano analizę skupień. Należy ona do metod wielowymiarowej analizy porównawczej (WAP), stanowiącej jeden z najważniejszych obszarów taksonomii numerycznej. Metody taksonomiczne poprzez zastosowanie odpowiednich wskaźników i miar umożliwiają dokonanie zestawień (grupowania) rozważanych wielocechowych obiektów ze względu na różne kryteria ${ }^{27}$. W niniejszym badaniu analiza skupień posłużyła grupowaniu krajów UE z punktu widzenia instytucjonalnego kontekstu wydłużania okresu aktywności zawodowej. W badaniu wykorzystano analogiczne jak w kroku pierwszym zmienne, przy czym powszechność wcześniejszych emerytur mierzono pośrednio oczekiwaną długością okresu pracy zawodowej (duration of working life) kobiet i mężczyzn. Z uwagi na znaczenie wieku emerytalnego dla prowadzonych analiz, zmienne te uwzględniono pomimo ich niskiego zróżnicowania (współczynnik zmienności rzędu 2-4\%). Stopę bezrobocia przekształcono do postaci stymulanty, zaś wszystkie zmienne poddano transfor-

${ }^{26}$ D. Hofäcker, In line or at odds with active ageing policies? Exploring patterns of retirement preferences...

27 Szczegółowe omówienie tych metod znaleźć można w: E. Nowak, Metody taksonomiczne w klasyfikacji obiektów społeczno-gospodarczych, Warszawa 1990; J. Korzeniewski, Metody selekcji zmiennych w analizie skupień. Nowe Procedury, Łódź 2012; A. Młodak, Analiza taksonomiczna w statystyce regionalnej, Warszawa 2006; T. Panek, J. Zwierzchowski, Statystyczne metody wielowymiarowej analizy porównawczej. Teoria i zastosowania, Warszawa 2013; M. Walesiak, E. Gatnar, Statystyczna analiza danych z wykorzystaniem programu R, Warszawa 2009; A. Zeliaś, Taksonomiczna analiza przestrzennego zróżnicowania poziomu życia w Polsce w ujęciu dynamicznym, Kraków 2002. 
macji normalizacyjnej z wykorzystaniem standaryzacji. Pomiaru odległości dokonano z wykorzystaniem metryki euklidesowej. Grupowanie obiektów przeprowadzono metodą Warda.

W ostatnim kroku oceniono znaczenie instytucjonalnego wsparcia wydłużania okresu aktywności zawodowej. Wykorzystując podstawowe metody oceny współzależności, zbadano relację między oceną omawianego wsparcia a podstawowymi wskaźnikami sytuacji osób starszych na rynku pracy.

\subsection{Wyniki badań empirycznych}

W świetle przeprowadzonych analiz, dla żadnego z krajów UE wskaźnik IFEWL nie osiągnął wartości maksymalnej (tabela 1), a jego obszar zmienności to przedział [1,33; 3,67]. Na pierwszej pozycji znalazły się, ex aequo, Dania i Finlandia, uzyskując 3,77 pkt, na kolejnych pozycjach plasuje się Holandia i Szwecja (3,5 pkt). W krajach tych jedynie stopa bezrobocia osób starszych oceniona została na 3 pkt (pozostałe obszary oceniono maksymalnie). Niewiele niższą punktację uzyskały kraje anglosaskie - Austria, Francja, Niemcy, Wielka Brytania (IFEWL powyżej 3 pkt).

Tabela 1. Instytucjonalny kontekst wydłużania okresu aktywności zawodoweja

\begin{tabular}{|c|c|c|c|c|c|c|c|c|c|c|c|}
\hline \multirow{3}{*}{$\begin{array}{c}\text { Kraj } \\
\text { Dania }\end{array}$} & \multicolumn{2}{|l|}{ Pull } & \multirow{2}{*}{\multicolumn{2}{|c|}{\begin{tabular}{|c|} 
Push \\
Bezrobo- \\
cie \\
$(50-64$ \\
lata) \\
$(2014$ r. $)$ \\
\end{tabular}}} & \multicolumn{5}{|c|}{ Stay } & \multirow{3}{*}{$\begin{array}{l}, 67 \\
3,5\end{array}$} & \multirow[b]{3}{*}{1} \\
\hline & \multicolumn{2}{|l|}{ Wiek emerytalny (2015 r.) } & & & \multicolumn{2}{|c|}{$\begin{array}{c}\text { LLL } \\
(45-54 \\
\text { lata) } \\
\text { (2014 r.) }\end{array}$} & \multicolumn{2}{|c|}{$\begin{array}{c}\text { ALMP } \\
\text { jako \% } \\
\text { PKB } \\
(2013 \text { r.) }\end{array}$} & \multirow{2}{*}{$\begin{array}{c}\text { Śr. } \\
4,0\end{array}$} & & \\
\hline & $\begin{array}{l}\text { 65K i M }{ }^{1}, \\
\text { bez wczesnych wyjść z RP }\end{array}$ & 4 & 4,8 & 3 & 28,8 & 4 & 3,36 & 4 & & & \\
\hline Finlandia & $\begin{array}{l}\text { 62-68M i K, } \\
\text { bez wczesnych wyjść z RP }\end{array}$ & 4 & 7,1 & 3 & 23,9 & 4 & 2,59 & 4 & 4,0 & 3,67 & 1 \\
\hline Holandia & $\begin{array}{l}65 \text { lat } 3 \text { mies. M i K }{ }^{2} \\
\text { bez wczesnych wyjść z RP }\end{array}$ & 4 & 7,2 & 3 & 16,1 & 3 & 2,78 & 4 & 3,5 & 3,50 & 1 \\
\hline Szwecja & $\begin{array}{l}\text { 61-67M, 61-67K, } \\
\text { bez wczesnych wyjść z RP }\end{array}$ & 4 & 5,3 & 3 & 26,3 & 4 & 1,99 & 3 & 3,5 & 3,50 & 1 \\
\hline Austria & $\begin{array}{l}\text { 65M, } 60 \mathrm{~K}^{3}, \\
\text { bez wczesnych wyjść z RP }\end{array}$ & 4 & 4,2 & 3 & 11,5 & 3 & 2,16 & 3 & 3,0 & 3,33 & 2 \\
\hline Francja & $\begin{array}{l}65 \mathrm{M} \mathrm{i} \mathrm{K}{ }^{4}, \\
\text { bez wczesnych wyjść z RP }\end{array}$ & 4 & 7 & 3 & 16,6 & 3 & 2,38 & 3 & 3,0 & 3,33 & 2 \\
\hline Niemcy & $\begin{array}{l}65 \text { lat } 3 \text { mies. M i K }{ }^{5} \\
\text { bez wczesnych wyjść z RP }\end{array}$ & 4 & 4,8 & 3 & 5,1 & 2 & 1,65 & 3 & 2,5 & 3,17 & 2 \\
\hline $\begin{array}{l}\text { Wielka } \\
\text { Brytania }\end{array}$ & $\begin{array}{l}\text { 65M, } 62 \text { lata } 4 \text { mies. } \mathrm{K}^{6}, \\
\text { bez wczesnych wyjść z RP }\end{array}$ & 3 & 3,9 & 4 & 15,2 & 3 & 0,68 & 2 & 2,5 & 3,17 & 2 \\
\hline Belgia & 65M i K, wczesne wyjścia z RP & 3 & 5,5 & 3 & 5,9 & 2 & 2,76 & 4 & 3,0 & 3,00 & 2 \\
\hline Irlandia & $\begin{array}{l}66 \mathrm{M} \mathrm{i} \mathrm{K}^{7} \\
\text { bez wczesnych wyjść z RP }\end{array}$ & 4 & 9,2 & 2 & 4,8 & 2 & 3,04 & 4 & 3,0 & 3,00 & 2 \\
\hline $\begin{array}{l}\text { Luksem- } \\
\text { burg }\end{array}$ & 65M i K, wczesne wyjścia z RP & 3 & 4,1 & 3 & 11,6 & 3 & 1,43 & 2 & 2,5 & 2,83 & 2 \\
\hline
\end{tabular}


Tabela 1 (cd.). Instytucjonalny kontekst wydłużania okresu aktywności zawodoweja

\begin{tabular}{|c|c|c|c|c|c|c|c|c|c|c|c|}
\hline \multirow{3}{*}{$\begin{array}{c}\text { Kraj } \\
\text { Włochy }\end{array}$} & \multicolumn{2}{|l|}{ Pull } & \multirow{2}{*}{\multicolumn{2}{|c|}{\begin{tabular}{|c|} 
Push \\
Bezrobo- \\
cie \\
$(50-64$ \\
lata) \\
$(2014$ r. $)$
\end{tabular}}} & \multicolumn{5}{|c|}{ Stay } & \multirow{3}{*}{ 2,83 } & \multirow{3}{*}{$\mathbf{S}$} \\
\hline & \multicolumn{2}{|l|}{ Wiek emerytalny (2015 r.) } & & & \multicolumn{2}{|c|}{$\begin{array}{c}\text { LLL } \\
(45-54 \\
\text { lata) } \\
(2014 \text { r. })\end{array}$} & \multicolumn{2}{|c|}{$\begin{array}{c}\text { ALMP } \\
\text { jako \% } \\
\text { PKB } \\
(2013 \text { r. })\end{array}$} & \multirow{2}{*}{\begin{tabular}{c|} 
Śr. \\
2,5
\end{tabular}} & & \\
\hline & $\begin{array}{l}\text { 66M, 64K, wczesne wyjścia } \\
\text { kobiet z RP }\end{array}$ & 3 & 6,5 & 3 & 6,4 & 2 & 1,93 & 3 & & & \\
\hline Hiszpania & $\begin{array}{l}65 \text { lat } 3 \text { mies. M i K } \\
\text { wczesne wyjścia z RP }\end{array}$ & 3 & 20,3 & 1 & 7,1 & 2 & 3,61 & 4 & 3,0 & 2,33 & 3 \\
\hline Polska & $\begin{array}{l}65 \text { lat } 6 \text { mies. } \mathrm{M} \text {, } \\
60 \text { lat } 6 \text { mies. } \mathrm{K}^{9} \text {, } \\
\text { wczesne wyjścia kobiet z RP }\end{array}$ & 2 & 6,9 & 3 & 2 & 2 & 0,83 & 2 & 2,0 & 2,33 & 4 \\
\hline Rumunia & $65 \mathrm{M}, 60 \mathrm{~K}^{10}$ & 2 & 4 & 4 & 0,8 & 1 & 0,25 & 1 & 1,0 & 2,33 & 4 \\
\hline $\begin{array}{l}\text { Portuga- } \\
\text { lia }\end{array}$ & $\begin{array}{l}66 \mathrm{M} \mathrm{i} \mathrm{K} \text {, wczesne wyjścia } \\
\text { kobiet z RP }\end{array}$ & 3 & 12,7 & 1 & 7,3 & 2 & 2,14 & 3 & 2,5 & 2,17 & 3 \\
\hline Słowenia & 64 lata 4 mies. $\mathrm{M}$ i K & 1 & 7,8 & 3 & 8,6 & 3 & 1,17 & 2 & 2,5 & 2,17 & 2 \\
\hline Cypr & $\begin{array}{l}\text { 65M i K, wczesne wyjścia } \\
\text { kobiet z RP }\end{array}$ & 3 & 15,3 & 1 & 4,9 & 2 & 1,34 & 2 & 2,0 & 2,00 & 3 \\
\hline Czechy & 62 lata 10 mies. M, 58-62 $\mathrm{K}^{11}$ & 1 & 5 & 3 & 8,5 & 3 & 0,54 & 1 & 2,0 & 2,00 & 4 \\
\hline Grecja & $\begin{array}{l}\text { 67M i K, wczesne wyjścia } \\
\text { kobiet z RP }\end{array}$ & 3 & 18,5 & 1 & 1,2 & 2 & 0,94 & 2 & 2,0 & 2,00 & 3 \\
\hline Węgry & 62 lata 6 mies. $\mathrm{M} \mathrm{i} \mathrm{K}^{12}$ & 1 & 6,1 & 3 & 2,3 & 2 & 1,12 & 2 & 2,0 & 2,00 & 4 \\
\hline Estonia & $63 \mathrm{M}, 62$ lata 6 mies. $\mathrm{K}^{13}$ & 1 & 6,1 & 3 & 7,7 & 2 & 0,68 & 2 & 2,0 & 2,33 & 4 \\
\hline $\begin{array}{l}\text { Chorwa- } \\
\text { cja }\end{array}$ & $65 \mathrm{M}, 61$ lat 3 mies. $\mathrm{K}^{14}$ & 2 & 12 & 2 & 0,9 & 1 & 0,71 & 2 & 1,5 & 1,83 & 4 \\
\hline Malta & $62 \mathrm{M} \mathrm{i} \mathrm{K}^{15}$ & 1 & 6,2 & 3 & 5,3 & 2 & 0,5 & 1 & 1,5 & 1,83 & 4 \\
\hline Słowacja & $62 \mathrm{M}, 58$ lat 3 mies., $62 \mathrm{~K}^{16}$ & 1 & 11,1 & 2 & 2,1 & 2 & 0,63 & 2 & 2,0 & 1,67 & 4 \\
\hline Bułgaria & $\begin{array}{l}64 \text { lata } 4 \text { mies.M, } \\
61 \text { lat } 4 \text { mies. } K\end{array}$ & 1 & 10,8 & 2 & 0,4 & 1 & 0,82 & 2 & 1,5 & 1,50 & 4 \\
\hline Litwa & $\begin{array}{l}63 \text { lata } 2 \text { mies. } \mathrm{M} \text {, } \\
61 \text { lat } 4 \text { mies. } \mathrm{K}^{17}\end{array}$ & 1 & 9,9 & 2 & 3,1 & 2 & 0,45 & 1 & 1,5 & 1,50 & 4 \\
\hline Łotwa & 62 lata 6 mies. $\mathrm{M} \mathrm{i} \mathrm{K}{ }^{18}$ & 1 & 9,8 & 2 & 3,7 & 2 & 0,53 & 1 & 1,5 & 1,50 & 4 \\
\hline
\end{tabular}

${ }^{1}$ W Danii WE stopniowo podnoszony do 67 lat do roku 2022, od 2030 r. będzie podnoszony maksymalnie o rok w ciągu 5 lat, zależnie od wydłużania życia; ${ }^{2} \mathrm{w}$ Holandii WE podnoszony stopniowo do 67 lat w 2024 r.; ${ }^{3}$ w Austrii wiek emerytalny (WE) K będzie zrównany z WE M (65 lat) w 2033 r.; ${ }^{4}$ we Francji WE podnoszony stopniowo do 67 lat w 2023 r.; ${ }^{5}$ w Niemczech WE podnoszony stopniowo do 67 lat w 2029 r.; ${ }^{6} \mathrm{w}$ Wlk. Brytanii WE K podnoszony stopniowo, do zrównania z WE M (65 lat) w 2018 r., później WE K i M będzie stopniowo podnoszony do 68 lat do 2046 r. lub wcześniej; ${ }^{7} \mathrm{w}$ Irlandii WE podnoszony stopniowo do 68 lat w $2028 \mathrm{r}$.; ${ }^{8} \mathrm{~W}$ Hiszpanii WE podnoszony stopniowo do 67 lat w 2027 r.; ${ }^{9}$ w Polsce WE stopniowo podnoszony do 67 lat (dla M w 2020 r., dla K w 2040 r.); ${ }^{10}$ w Rumunii WE stopniowo podnoszony do 63 lat w 2030 r.; ; ${ }^{11}$ w Czechach WE K zależy od liczby dzieci, w $2041 \mathrm{r}$. osiągnie 67 lat; ${ }^{12}$ na Węgrzech WE stopniowo podnoszony do 65 lat w 2022 r.; ${ }^{13}$ w Estonii WE K jest stopniowo podnoszony, w 2016 r. zrówna się z wiekiem M, 
w kolejnych latach emerytalny wiek K i M będzie podnoszony - do 65 lat w r. 2026; ${ }^{14}$ w Chorwacji do 2038 r. wiek emerytalny (WE) K i M będzie zrównany do 67 lat, w 2030 r. - dla K będzie on wynosił 65 lat; ${ }^{15}$ na Malcie WE podnoszony stopniowo do 65 lat w 2026 r.; ${ }^{16}$ w Słowacji WE K zależny od liczby dzieci, dla K i M stopniowo podnoszony do 62 lat w 2017 r.; ${ }^{17}$ na Litwie WE podnoszony stopniowo do 65 lat w 2026 r.; ${ }^{18}$ na Łotwie WE podnoszony stopniowo do 65 lat w 2025 r.; ${ }^{19} 2012$ r.; ${ }^{20} 2010$ r.; ${ }^{\text {a }}$ K - kobiety, M - mężczyźni, RP - rynek pracy, Śr. - średnia z ocen dwóch czynników typu stay, $\mathrm{S}$ - numer skupienia (grupowanie metodą Warda).

Źródło: opracowanie własne na podstawie danych Eurostatu [lfsa_urgan; lfsi_dwl_a; trng_lfse_01; lmp_ind_exp] oraz http://www.etk.fi.

W Polsce wskaźnik IEEWL jest na umiarkowanym poziomie, punktacja jest identyczna jak w przypadku Hiszpanii i Rumunii, przy czym jest to efekt wyższej oceny czynników push, wyraźnie niżej w Rumunii są natomiast oceniane w Polsce uwarunkowania typu stay. Najsłabiej oceniono uwarunkowania instytucjonalne w krajach nadbałtyckich oraz w Bułgarii.

Przeprowadzona analiza uzupełniona została o wyniki grupowania z wykorzystaniem analizy skupień. W ramach Unii Europejskiej można wyróżnić cztery grupy, jednorodne z punktu widzenia kontekstu instytucjonalnego aktywności zawodowej starszego pokolenia (por. ostatnia kolumna tabeli 1). Do grupy pierwszej zaliczają się cztery kraje, dla których uzyskano również najwyższą wartość indeksu IFEWL - Dania, Finlandia, Szwecja i Holandia. Jest to grupa, która wprawdzie nie ma najmocniejszej sytuacji z punktu widzenia czynnika push, ma natomiast najlepszą sytuację w obszarze pull i stay (tabela 2).

Tabela 2. Porównanie podstawowych statystyk rozkładu wybranych zmiennych w obrębie skupień

\begin{tabular}{|c|c|c|c|c|c|c|c|c|}
\hline \multirow{3}{*}{ Zmienne diagnostyczne } & \multicolumn{8}{|c|}{ Numer skupienia } \\
\hline & \multicolumn{2}{|c|}{1} & \multicolumn{2}{|c|}{2} & \multicolumn{2}{|c|}{3} & \multicolumn{2}{|c|}{4} \\
\hline & $\mathbf{M}$ & STD & $\mathbf{M}$ & STD & $\mathbf{M}$ & STD & M & STD \\
\hline Wiek emerytalny mężczyzn & 66,31 & 1,43 & 64,83 & 0,82 & 65,85 & 0,78 & 63,69 & 1,79 \\
\hline Wiek emerytalny kobiet & 66,31 & 1,43 & 63,70 & 1,76 & 65,85 & 0,78 & ' & 1,30 \\
\hline Długość karier zawodowych mężczyzn & 40,68 & 2,14 & 37,21 & 2,36 & 38,02 & 1,46 & 35,21 & 2,09 \\
\hline Długość karier zawodowych kobiet & 37,73 & 1,31 & 32,28 & 3,52 & 31,64 & 2,59 & 30,22 & 2,76 \\
\hline Stopa bezrobocia (50-64) & 6,10 & 1,23 & 5,54 & 1,40 & 15,20 & 4,45 & 8,18 & 2,85 \\
\hline Wskaźnik lifelong learning & 23,78 & 5,49 & 9,84 & 4,13 & 5,06 & 2,46 & 2,91 & 2,46 \\
\hline Wydatki na ALMP jako \% PKB & 2,68 & 0,56 & 1,65 & 0,73 & 2,22 & 1,12 & 0,64 & 0,24 \\
\hline IFEWL & 3,59 & 0,10 & 2,80 & 0,66 & 2,30 & 0,41 & 1,85 & 0,32 \\
\hline Wskaźnik zatrudnienia ogółem (50-64) & 70,33 & 5,19 & 60,56 & 7,77 & 53,16 & 6,23 & 55,48 & 7,17 \\
\hline $\begin{array}{l}\text { Wskaźnik zatrudnienia mężczyzn } \\
(50-64)\end{array}$ & 73,68 & 6,38 & 66,21 & 7,02 & 61,52 & 5,13 & 62,42 & 5,12 \\
\hline Wskaźnik zatrudnienia kobiet (50-64) & 66,90 & 7,05 & 54,97 & 9,58 & 45,22 & 7,58 & 48,93 & 11,67 \\
\hline
\end{tabular}

M - średnia arytmetyczna, STD - odchylenie standardowe

Źródło: obliczenia własne na podstawie danych Eurostatu [lfsa_urgan; lfsi_dwl_a; trng_lfse_01; lmp_ind_exp] oraz http://www.etk.fi. 
Grupowanie krajów UE w dużej mierze potwierdza ranking skonstruowany w oparciu o wskaźnik IFEWL. W drugiej grupie znalazły się głównie kraje anglosaskie (tabela 1). Kraje te wyróżniają się pod względem czynników stay, w tym zwłaszcza skali zaangażowania starszego pokolenia w kształcenie ustawiczne. Czynniki pull są średnio rzecz biorąc na nieco niższym poziomie niż w skupieniu 1. i 3., wyższym zaś niż w grupie 4. Grupa ta jest dość liczna - obejmuje 9 krajów, w przeciwieństwie do kolejnego skupienia - w trzecim znalazły się tylko cztery kraje śródziemnomorskie (Cypr, Grecja, Portugalia i Hiszpania tabela 1).

W grupie trzeciej wydłużanie aktywności zawodowej próbuje się stymulować zwłaszcza przez czynniki pull, relatywnie duże są też nakłady na AMLP, niemniej jednak trudna sytuacja na rynku pracy i związane z tym wysokie bezrobocie osób w wieku 50+, jak również słabe zaangażowanie starszego pokolenia w kształcenie ustawiczne powodują, że wyjścia z rynku pracy są wczesne. Ma to swój związek z polityką społeczną realizowaną w krajach basenu Morza Śródziemnego (reżim śródziemnomorski - model ,państwa opiekuńczego", obejmującego znaczną opieką osoby starsze, wypłacającego wysokie świadczenia emerytalne, ale mające słabą politykę rodzinną i system świadczeń z tytułu bezrobo$\mathrm{cia}^{28}$.

W tej sytuacji, pomimo podejmowanych prób „usztywnienia” systemu, emerytura jest atrakcyjną alternatywą dla kontynuowania kariery zawodowej. W ostatniej grupie z kolei znalazły się prawie wszystkie kraje członkowskie Europy Środkowej i Wschodniej, w tym Polska (tabela 1). W skupieniu tym jedynie czynniki typu push kształtują się relatywnie dobrze, niemniej jednak zarówno uwarunkowania typu pull, jak i stay pozostają na słabym poziomie (tabela 2).

Zestawiając uzyskane wyniki z wartościami wskaźników zatrudnienia dla poszczególnych krajów UE można zauważyć, że wydłużaniu okresu aktywności zawodowej w największym stopniu sprzyjają trzy czynniki (tabela 3). Przede wszystkim jest to ograniczenie możliwości i wypracowanie ,kultury” przechodzenia na wcześniejszą emeryturę, zwłaszcza przez kobiety. Drugim co do ważności czynnikiem jest rozwój kompetencji poprzez zaangażowanie kobiet i mężczyzn w kształcenie ustawiczne, również po 50. roku życia. W przypadku mężczyzn skłonność do dezaktywizacji zawodowej pozostaje w silnym związku z sytuacją na rynku pracy - w krajach, w których stopa bezrobocia osób w wieku 50+ jest wyższa, emerytura staje się bezpiecznym źródłem dochodu, jeśli zatem istnieje możliwość skorzystania z niej, mężczyźni po 50. roku życia chętnie to czynią (dla kobiet zależność ta jest słabsza, aczkolwiek jej kierunek również jest ujemny). Niewielkie jest natomiast znaczenie kształtowania systemu emerytalnego w zakresie granicy powszechnego wieku emerytalnego, jak również prowadzona polityka ALMP (w wymiarze jej znaczenia w polityce rynku pracy, niż jej ,struktury”, która była tu pomijana, aczkolwiek jak wskazują inne badania, spośród instrumentów ALMP najlepsze efekty przynoszą te związane z kształceniem ustawicznym ${ }^{29}$ ).

28 G. Esping-Andersen, The Three World of Welfare Capitalism, New York 1990.

${ }^{29}$ B. Urbaniak, J. Wiktorowicz, Support for Economic Activity of People Aged 50+ in Poland: the Best Solutions of the Goverment's Programme Solidarity of Generations, "Comparative Economic Research. Central and Eastern Europe", 17/1, 2014, s. 77-92 
Tabela 3. Instytucjonalne uwarunkowania wydłużania okresu aktywności zawodowej a wskaźnik zatrudnienia osób w wieku 50-64 lata w UE

\begin{tabular}{|l|c|c|c|}
\hline \multirow{2}{*}{\multicolumn{1}{|c|}{ Zmienne diagnostyczne }} & \multicolumn{3}{c|}{ Wskaźnik zatrudnienia (50-64 lata) } \\
\cline { 2 - 4 } & ogółem & mężczyźni & kobiety \\
\hline Wiek emerytalny mężczyzn & 0,060 & 0,038 & 0,069 \\
Wiek emerytalny kobiet & 0,224 & 0,189 & 0,212 \\
Długość karier zawodowych mężczyzn & $\mathbf{0 , 5 7 0}$ & $\mathbf{0 , 7 8 2}$ & 0,381 \\
Długość karier zawodowych kobiet & $\mathbf{0 , 8 3 9}$ & $\mathbf{0 , 6 2 1}$ & $\mathbf{0 , 8 6 6}$ \\
Stopa bezrobocia (50-64) & $-0,457$ & $\mathbf{- 0 , 5 1 8}$ & $-0,361$ \\
Wskaźnik lifelong learning & $\mathbf{0 , 6 4 3}$ & $\mathbf{0 , 5 9 5}$ & $\mathbf{0 , 5 8 6}$ \\
Wydatki na ALMP jako \% PKB & 0,272 & 0,329 & 0,316 \\
IFEWL & 0,435 & 0,495 & 0,343 \\
\hline
\end{tabular}

W tabeli podano wartości współczynnika korelacji liniowej Pearsona. Boldem oznaczono relatywnie wysokie współczynniki korelacji $(|r|>0,5)$. Pozostałe oznaczenia - jak w tabeli 2

Źródło: obliczenia własne na podstawie danych Eurostatu [lfsa_urgan; lfsi_dwl_a; trng_lfse_01; lmp_ind_exp] oraz http://www.etk.fi.

Uzyskane wyniki potwierdzają przytaczane wcześniej wnioski z dotychczasowych prac badawczych. Pamiętać przy tym należy, że współczynniki korelacji nie wyjaśniają jeszcze związków przyczynowo-skutkowych.

\section{PODSUMOWANIE}

Przeprowadzona analiza potwierdza słuszność podejścia przyjętego przez Hofäckera wśród instytucjonalnych uwarunkowań wydłużania okresu aktywności zawodowej oprócz czynników typu pull, push istotne znaczenie odgrywają determinanty typu stay. Kraje Unii Europejskiej, które zajmują czołowe pozycje z tego punktu widzenia, tj. kraje skandynawskie, charakteryzuje wysoka na tle innych aktywność zawodowa również starszej części społeczeństwa. Spośród czynników instytucjonalnych, ze wskaźnikami zatrudnienia (ogółem i według płci) najsilniej powiązany jest jeden z instrumentów typu stay - lifelong learning, natomiast sytuacja na rynku pracy, mierzona stopą bezrobocia (czynnik typu push) jest relatywnie silnie powiązana $\mathrm{z}$ aktywnością zawodową mężczyzn. Podkreślić należy względnie słabe znaczenie poziomu ustawowego wieku emerytalnego, przy dość silnym oddziaływaniu długości kariery zawodowej, która jest wypadkową również preferencji osób w wieku 50+, w tym zwłaszcza czynników indywidualnych (kapitału ludzkiego, sytuacji rodzinnej itp.) ${ }^{30}$. Ogólnie rzecz biorąc, uwarunkowania instytucjonalne wydłużania okresu aktywności zawodowej w większym stopniu oddziałują na poziom wskaźników zatrudnienia w UE w przypadku mężczyzn niż kobiet. Słabe znaczenie ALMP koresponduje z tym, że w odniesieniu do osób w wieku 50+ bardziej skuteczne są działania służące utrzymaniu ich w zatrudnieniu niż ponownemu zatrudnieniu po utracie pracy. Uzyskane wyniki potwierdzają zatem, że przyjęte przed laty kierunki polityki społecznej, w tym zwłaszcza

30 J. Wiktorowicz, Międzypokoleniowy transfer wiedzy a wydtużanie okresu aktywności zawodowej, Łódź 2016. 
nacisk, jaki kładzie się na rozwój kompetencji starszego pokolenia w ramach polityki aktywnego starzenia się, pozostają aktualne.

\section{LITERATURA}

1. Barrell R., Hurst I, Kirby S., Macroeconomic implications of pension reform or how to pay for the crisis [w:] Pension Reform, Fiscal Policy and Economic Performance, Workshops and Conferences, Banca d'Italia, Roma 2009.

2. Bukowski M. (red.), Zatrudnienie w Polsce 2008. Praca w cyklu życia, CRZL, Warszawa 2010 .

3. Burtless G., Bosworth B.P., Impact of the Great Recession on retirement trends in industrialized countries, "Center for Retirement Research Working Paper" 2013-23, Boston College, Boston 2013.

4. Chłoń-Domińczak A., Ekonomiczne skutki i uwarunkowania niskiej aktywności zawodowej osób 50+ w Polsce [w:] Aktywizacja zawodowa osób 50+ i zarzadzanie wiekiem. Informacje użyteczne dla instytucji rynku pracy, Akademia Rozwoju Filantropii w Polsce, Warszawa 2010.

5. De Preter H., Van Looy D., Mortelmans D., Individual and institutional push and pull factors as predictors of retirement timing in Europe: A multilevel analysis, "Journal of Aging Studies", 27, 2013.

6. Domańska A., Zajkowski R., Raport z badań kluczowych przeprowadzonych na potrzeby realizacji projektu «PI - Wirtualny Asystent Kariery 50+» (WAK50), PAIP, Lublin 2013.

7. Esping-Andersen G., The Three World of Welfare Capitalism, Princeton University Press, Princeton, New York 1990.

8. Funk L., Employment Opportunities for Older Workers: A Comparison of Selected OECD Countries, DICE Research Report 2004.

9. Hofäcker D., In line or at odds with public policies? Individual retirement preferences in a changing pension landscape, Paper for the ESPAnet Anniversary Conference 2012 Edinburgh, 6-8.09.2012.

10. Hofäcker D., In line or at odds with active ageing policies? Exploring patterns of retirement preferences in Europe, "Ageing and Society", V35(7), 2015.

11. Jurek Ł., Ekonomia starzejącego się społeczeństwa, Difin, Warszawa 2012.

12. Kalwij A., Kapteyn A., de Vos K., Retirement of older workers and employment of the young, "De Economist", 158(4), 2010.

13. Korzeniewski J., Metody selekcji zmiennych w analizie skupień. Nowe Procedury, Wydawnictwo Uniwersytetu Łódzkiego, Łódź 2012.

14. Młodak A., Analiza taksonomiczna w statystyce regionalnej, Difin, Warszawa 2006.

15. Munnell A.H., Soto M., Triest R.K., Zhiven N.A., How Much o State Economic and Other Characteristics Affect Labor Force Participation of Older Workers?, "Center for Retirement Research Working Paper" 2008-12, Boston College, Boston 2008.

16. Munnell A.H., Wu A.Y., Will delayed retirement by the baby boomers lead to higher unemployment among younger workers?, "Center for Retirement Research Working Paper" 2012-22, Boston College, Boston 2012.

17. Nowak E., Metody taksonomiczne w klasyfikacji obiektów społeczno-gospodarczych, PWE, Warszawa 1990. 
18. Ondrich J., Falevich A., The Great Recession and the retirement decisions of older workers, "Center for Retirement Research Working Paper" 2013-24, Boston College, Boston 2013.

19. Panek T., Zwierzchowski J., Statystyczne metody wielowymiarowej analizy porównawczej. Teoria i zastosowania, Oficyna Wydawnicza, Szkoła Główna Handlowa w Warszawie, Warszawa 2013.

20. Phillipson Ch., Smith A., Extending working life: A review of the research literature, Department for Work and Pensions, Research Report No 299, 2005.

21. Polakowski M., Społeczne i ekonomiczne konsekwencje starzenia się społeczeństw a główne kierunki reform systemów emerytalnych w Europie, ,Studia BAS”, 2(30), 2012, s. 169-200.

22. Rutledge M.S., Point of no return: how do financial resources and the timing of retirement after a Job separation, "Center for Retirement Research Working Paper" 2013-21, Boston College, Boston 2013.

23. Rutledge M.S., Orlova N., Webb A., How will Older workers who lose their jobs during the Great Recession fare in the long-run?, "Center for Retirement Research Working Paper" 2013-9, Boston College, Boston 2013.

24. Strzelecki P., Saczuk K., Grabowska I., Kotowska I.E., Rynek pracy [w:] J. Czapiński, T. Panek (red.), Diagnoza Społeczna 2013. Warunki i Jakość Życia Polaków - Raport, MPiPS, CRZL, Warszawa 2014.

25. Unwin L., Davey G., Fuller A., Leonard P., Supporting an Ageing Workforce: Implications for Working Life, Training and Skills Policy in England - a Literature Review, "LLAKES Research Paper" 51, Centre for Learning and Life Chances in Knowledge Economies and Societies, 2015.

26. Urbaniak B., Wiktorowicz J., Support for Economic Activity of People Aged 50+ in Poland: the Best Solutions of the Goverment's Programme Solidarity of Generations, "Comparative Economic Research. Central and Eastern Europe", 17/1, 2014.

27. Van Oorschot W., Jensen P.H., Early retirement differences between Denmark and The Netherlands. A cross-national comparison of push and pull factors in two small European welfare states, "Journal of Aging Studies", Vol. 23, Issue 4, 2009.

28. Von Wachter T., The effect of economic conditions on the employment of workers nearing retirement age, "Center for Retirement Research Working Paper" 2007-25, Boston College, Boston 2007.

29. Walesiak M., Gatnar E., Statystyczna analiza danych z wykorzystaniem programu $R$, Wydawnictwo Naukowe PWN, Warszawa 2009.

30. Walker A., Early Retirement: Release or Refuge from the Labour Market?, "The Quarterly Journal of Social Affairs", 1(3), 1985.

31. Wiktorowicz J., Międzypokoleniowy transfer wiedzy a wydtużanie okresu aktywności zawodowej, Wydawnictwo Uniwersytetu Łódzkiego, Łódź 2016.

32. Zeliaś A., Taksonomiczna analiza przestrzennego zróżnicowania poziomu życia w Polsce $w$ ujęciu dynamicznym, Wydawnictwo Akademii Ekonomicznej w Krakowie, Kraków 2002.

\section{NETOGRAFIA}

1. http://www.etk.fi (dostęp: 21.04.2016 r.).

2. Eurostat [lfsa_urgan; lfsi_dwl_a; trng_lfse_01; lmp_ind_exp] (dostęp: 13.03.2017 r.). 


\section{INSTITUTIONAL FACTORS OF EXTENDING WORKING LIFE}

Nowadays extending working life is the important direction of social policy. It caused that the research on the factors of retirement decisions are still important. The concept of pull and push factors provides the explanation of them. This classification is supplemented with stay factors by Hofäcker. These factors include the support of employability of older workers through a different active labour market policy measures and lifelong learning. The aim of this paper is the assessment of the role of institutional determinants of extending working life in the European Union countries. An empirical analysis was conducted on the basis of LFS data, with using of the main independence methods and cluster analysis. The study was carried out in two ways. First, using the methodology proposed by Hofäcker, the results of his research for the year 2010 were updated, complementing the analysis with the omitted EU countries. At this stage, a synthetic indicator of the assessment of institutional determinants of extending working life was calculated. In the second step, cluster analysis was used to group EU countries from the point of view of the studied phenomenon (using the characteristics similar to those in the first stage). In the last stage, the correlation between the economic activity of older people and synthetically analysed institutional conditions was assessed. The results show that in the European Union among the institutional determinants of extending working life, in addition to the pull factors, push factors play the important role. In general, the analysed institutional conditions have a greater impact on the level of employment rates in the European Union in the case of men than women. The weak importance of active labor market policy (ALMP) corresponds to the fact that in relation to people aged 50+, measures to maintain them in employment are more effective than reemployment after losing a job.

Keywords: ageing, labour market policy, retirement, EU.

DOI: $10.7862 /$ rz.2018.hss.35

Przestano do redakcji: grudzień 2018 r.

Przyjęto do druku: czerwiec 2018 r. 